\title{
Diffuse pigmented villonodular synovitis in a child - what is the best management?
}

\author{
Sharmin Nizam*, Lesley D Hordon \\ From Northern and Yorkshire Deaneries Annual Rheumatology Conference \\ York, UK. 26 September 2012
}

\section{Case}

A 5 year old boy presented to orthopaedics in 2004 with a 3-4 month history of intermittent left knee pain. As examination was normal he required no specific treatment. In 2007, he attended A\&E with a spontaneous left knee effusion with a CRP of $9 \mathrm{mg} / \mathrm{l}$, ESR $9 \mathrm{~mm} / \mathrm{h}$, raised platelet count of $559\left(10^{9} / \mathrm{l}\right)$ and mild neutrophilia of 9.23 $\left(10^{9} / \mathrm{l}\right)$. Knee $\mathrm{x}$-ray was normal. $20 \mathrm{mls}$ of haemorrhagic fluid was aspirated (cultures negative). 2 months later, he was seen by rheumatologists due to fluctuant swelling, initially responding to oral non-steroidals but later requiring an intra-articular injection $(20 \mathrm{mg}$ triamcinolone). MRI imaging suggested PVNS.

Synovial biopsy or synovectomy was avoided due to risk of post-op stiffness. JIA was considered after 2 left knee flares following upper respiratory tract infections and transient right knee swelling. However, imaging $(2007,2009,2012)$ and aspirate appearances were typical of PVNS.

Screening over 5 years revealed no evidence of uveitis. He was ANA negative and there was no history of psoriasis.

In 2009, a further intra-articular injection $(20 \mathrm{mg}$ triamcinolone) was required. The patient remained well and active with ibuprofen and physiotherapy until a preholiday flare in May 2012. His GP injected the knee, after aspirating blood, with $40 \mathrm{mg}$ triamcinolone with no response. He was referred to our service for review. Repeat MRI (Figure 1) showed progressive changes. As the differential diagnosis includes recurrent haemarthrosis, synovial biopsy has been advised.

\section{Discussion}

Pigmented villonodular synovitis (PVNS) is a rare cause of monoarthritis. Haemorrhagic effusions and typical imaging appearances (reduced signal on T1\&T2weighted MRI or hyperdensity on CT) are typical. Histology reveals hypervascular, proliferative synovium $[1,2]$. Insidious presentation can cause delays in diagnosis, especially in children, with potential adverse effect on prognosis [1]. Although a "benign" condition, it can cause significant joint damage and disability due to recurrent synovitis [3]. Arthroscopic/open synovectomies are recommended. Neither treatment guarantees complete eradication of affected tissue and recurrence is common [3-5]. Surgery can lead to post-op stiffness, instability and secondary osteoarthritis. Post-op adjuvant radiotherapy (low dose external beam) may reduce recurrence. Long term benefits are controversial and in

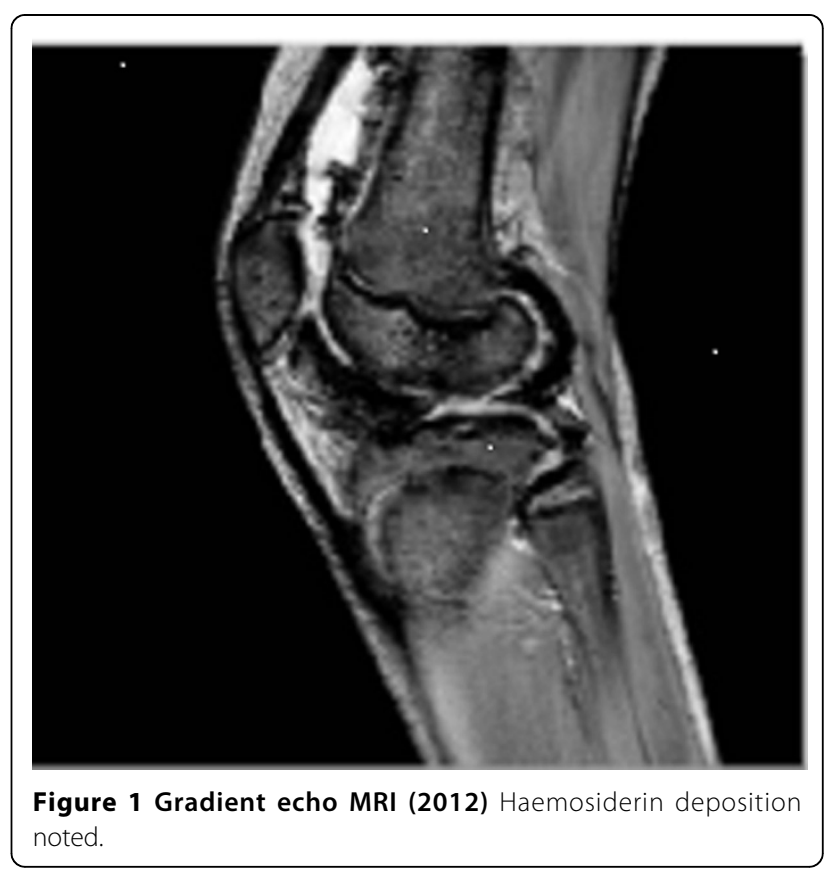


paediatric cases, raise concern about risks of epiphyseal growth plate damage and post radiation sarcoma $[4,5]$. Evidence of benefit with anti-TNF (infliximab) and tyrosine kinase inhibitor therapies is currently limited to case reports and preliminary phase II study data. Management is thus difficult, particularly in children, because of long term complications of both the disease and treatment.

\section{Acknowledgements}

Patient and family for consent.

Published: 14 February 2013

\section{References}

1. DeLaney TF: Antineoplastic therapy for miscellaneous benign diseases affecting soft tissue and bone. 2012 [http://www.uptodate.com], (accessed Aug 2012).

2. Modarresi S, Jude CM: Radiologic evaluation of knee tumours in adults. 2012 [http://www.uptodate.com], (accessed August 2012).

3. Baroni E, Dello Russi B, Masquijo J, et al: Pigmented villonodular synovitis of the knee in skeletally immature patients. J Child Orthop 2010 4:123-127.

4. Park G, Kim YS, Kim JH, et al: Low dose external beam radiotherapy as a post operative treatment for patients with diffuse pigmented villonodular synovitis of the knee. Acta Orthopaedica 2012, 83(3):256-260.

5. Nakahara $\mathrm{H}$, et al: Clinical results of open synovectomy for management of diffuse pigmented villonodular synovitis of the knee:case series and review of literature. Knee 2012, 19(5):684-687.

doi:10.1186/1471-2474-14-S1-A6

Cite this article as: Nizam and Hordon: Diffuse pigmented villonodular synovitis in a child - what is the best management? BMC Musculoskeletal Disorders 2013 14(Suppl 1):A6.

\section{Submit your next manuscript to BioMed Central} and take full advantage of:

- Convenient online submission

- Thorough peer review

- No space constraints or color figure charges

- Immediate publication on acceptance

- Inclusion in PubMed, CAS, Scopus and Google Scholar

- Research which is freely available for redistribution

Submit your manuscript at www.biomedcentral.com/submit 